\title{
Effect of TLR2 on the proliferation of inflammation-related colorectal cancer and sporadic colorectal cancer
}

\author{
Shuang Meng ${ }^{1,2}$, Yingjie Li ${ }^{1}$, Xiaozhen Zang ${ }^{1}$, Zheng Jiang ${ }^{3}$, Huahan Ning ${ }^{1}$ and Jing $\mathrm{Li}^{i^{*}}$ (0)
}

\begin{abstract}
Background: Colitis-associated cancer (CAC) is a complication of inflammatory bowel disease (IBD) with a poor prognosis because it is often diagnosed in advanced stages with local progression or metastasis. Compared with the more common polyp-induced sporadic colorectal cancer (sCRC), CAC has different molecular mechanisms. Toll-like receptor 2 (TLR2) expression is not limited to cells related to inflammation and immune function. High levels of TLR2 expression in tumor tissues of colorectal cancer (CRC) patients have been reported. This report is to investigate the effects of knockout and knockdown of the TLR2 gene on the proliferation of CAC and SCRC.

Methods: Twelve C57BL/6 J wild-type mice (WT) and 12 TLR2 knockout mice (TLR2-/-) were used to rapidly establish a colitis-associated cancer (CAC) model via the 1,2-dimethylhydrazine-dextran sodium sulfate (DMH-DSS) method and were divided into the normal WT control group (NC), TLR2 knockout control group (KC), normal wild-type tumor modeling group (NT), and TLR2 knockout tumor modeling group (KT), with 6 mice in each group. The general performance of the mice during modeling, the gross changes of the colon and the rectum, and the pathological score of HE staining were used to observe tumor growth. The expression of TLR2 was detected by immunohistochemistry, and tumor proliferation was detected by Ki67 labeling. Lentivirus carrying TLR2-RNAi was used to stably infect colorectal cancer cells (HCT116 and HT29) to knock down TLR2 gene expression. The experimental groups included the uninfected control group, negative control group, and gene knockdown group. After infection, the expression of TLR2 protein was detected by Western blot, and cell proliferation and the cell cycle were detected by the CCK-8 method and fluorescence-activated cell sorting. Western blot was used to detect the expression levels of $\mathrm{p}-\mathrm{NF}-\mathrm{k} \beta$, cyclin D1 and cyclin D3 protein in each group of cells.
\end{abstract}

Results: TLR2 knockout in the CAC model resulted in greater changes in body weight and more severe diarrhea and colorectal hemorrhage. However, knocking out the TLR2 gene reduced the shortening of colorectal length, the number of tumors, and the total tumor volume and inhibited the growth of CAC. Knocking out the TLR2 gene also reduced the pathological score and tumor severity. TLR2 was localized in the cell membrane of the colorectal epithelium of the NC group and of the colorectal tumors of the NT group and was highly expressed in the NT group, while antigen Ki67 was localized in the nucleus of the colorectal tumor cells of the NT group and the KT group, and its expression was reduced in the KT group. In an in vitro sporadic colorectal cancer cell experiment, TLR2 protein in the TLR2 knockdown group was significantly downregulated, and TLR2 knockdown significantly inhibited the

\footnotetext{
*Correspondence: 945331470@qq.com

${ }^{1}$ Department of Gastroenterology, The First Affiliated Hospital of Jinzhou

Medical University, No. 2, Section 5 Renmin Street, Guta District, Jinzhou

City 121001, Liaoning Province, China

Full list of author information is available at the end of the article
}

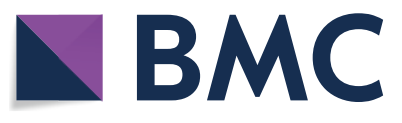

(c) The Author(s) 2020. This article is licensed under a Creative Commons Attribution 4.0 International License, which permits use, sharing, adaptation, distribution and reproduction in any medium or format, as long as you give appropriate credit to the original author(s) and the source, provide a link to the Creative Commons licence, and indicate if changes were made. The images or other third party material in this article are included in the article's Creative Commons licence, unless indicated otherwise in a credit line to the material. If material is not included in the article's Creative Commons licence and your intended use is not permitted by statutory regulation or exceeds the permitted use, you will need to obtain permission directly from the copyright holder. To view a copy of this licence, visit http://creativeco mmons.org/licenses/by/4.0/. The Creative Commons Public Domain Dedication waiver (http://creativecommons.org/publicdomain/ zero/1.0/) applies to the data made available in this article, unless otherwise stated in a credit line to the data. 
proliferation of HCT116 and HT29 colorectal cancer cells, resulting in G1 phase arrest. The expression levels of p-NF-K $\beta$, cyclin D1 and cyclin D3 proteins in TLR2 gene knockdown group cells were significantly reduced.

Conclusion: Knockout and knockdown of TLR2 can inhibit the proliferation of inflammation-related colorectal cancer and sporadic colorectal cancer.

Keywords: Inflammation-related colorectal cancer, Sporadic colorectal cancer, Toll-like receptor 2, Cell proliferation

\section{Background}

Colorectal cancer (CRC) is one of the most commonly diagnosed malignant tumors in the world. It is ranked fourth among all male malignancies and third among all female malignancies and is the fourth-leading cause of cancer death in the world. In 2012, the number of new CRC cases was approximately 1.4 million, and the number of deaths was nearly 700,000 [1, 2]. By 2030, the global burden of colorectal cancer is expected to increase by $60 \%$, reaching more than 2.2 million new cases and 1.1 million deaths [2]. Genetic and microenvironmental factors have been identified as key risk factors for CRC, with chronic inflammation being an important risk factor, and up to $20 \%$ of cases are associated with chronic infections [3]. Sporadic colorectal cancer (sCRC) is the predominant form of CRC, accounting for more than $90 \%$ of CRC cases and occurring in people with no family history of this disease. This type of cancer usually results from continuous accumulation of genetic mutations in genes that control epithelial cell growth and differentiation and is often accompanied by inflammatory manifestations [4, 5]. One type of inflammation occurring before the onset of tumorigenesis is a chronic inflammation caused by immune disorders and autoimmunity. A typical example is inflammatory bowel disease (IBD), which greatly increases the risk of malignancy [6]. Colitis-associated cancer (CAC) is a complication of IBD with a poor prognosis because it is often diagnosed in advanced stages with local progression or metastasis [7]. Compared with the more common polyp-induced sCRC, CAC has different molecular mechanisms [8].

Toll-like receptors (TLRs) are innate immune sensors that recognize a variety of pathogenic components, called pathogen-associated molecular patterns, and can initiate proinflammatory responses to maintain intestinal homeostasis [9]. TLRs not only are an important part of the innate immune system but also activate the adaptive immune system and are widely involved in infectious diseases, inflammatory and allergic diseases, and carcinogenesis $[10,11]$. Currently, 10 human TLRs and 13 mouse TLRs have been identified [9]. In the past, most studies have focused on intracellular TLRs such as TLR3, TLR7, and TLR9, but recent studies have shown that cell-surface TLRs, particularly TLR2, also play an important role in the development of autoimmune diseases, and TLR2 expression is not limited to cells related to inflammation and immune function [12]. The expression of functional TLR2 is found in epithelial cells, while TLR2 is also expressed in many tumor cells and tissues [13]. High levels of TLR2 expression in tumor tissues of CRC patients have been reported $[10,14]$. It is clear that TLR2 plays an important role in the pathogenesis and development of colorectal cancer. However, the role of TLR2 in CAC and sCRC remains to be further clarified, which may provide promising new targets for $\mathrm{CAC}$ and sCRC anticancer therapy.

\section{Materials and methods \\ Animal}

TLR2 knockout mice (TLR2-/-) were from the Jackson Laboratory (USA), and C57BL/6 J wild-type mice (WT) were purchased from Beijing HFK Bioscience Co. Ltd. After approval by the Ethics Committee of Jinzhou Medical University, the animals were raised in the specific pathogen-free (SPF)-grade laboratory animal center of Jinzhou Medical University.

\section{Induction of CAC model}

Mice were divided into a normal WT control group (NC), TLR2 knockout control group (KC), normal WT tumor modeling group (NT), and TLR2 knockout tumor modeling group (KT). For the modeling groups, 12 8 -week-old female mice (6 TLR2-/- and 6 WT) were intraperitoneally injected with $40 \mathrm{mg} / \mathrm{kg}$ of 1,2-dimethylhydrazine (DMH: Sigma, Germany) on days 1, 3, and 5 . Starting from the 12th day, the mice received water containing 3\% dextran sulfate sodium (DSS: MP Biomedical, USA) for 5 days and then received 12 days of regular drinking water. From the 5th day of DSS water treatment, the mice received injections of $0.9 \% \mathrm{NaCl}$ at $0.8 \mathrm{ml} /$ day for 3 days. The mice were subjected to 2 DSS cycles, followed by a third cycle in which the mice were given $3 \%$ DSS water for 4 days and then regular water for 11 days, and they received injections of $0.9 \% \mathrm{NaCl}$ on the 4th, 5 th, and 6th days of drinking DSS at $0.8 \mathrm{ml} /$ day. For the control groups, 12 8-week-old female mice (6 TLR2-/- and $6 \mathrm{WT})$ received regular drinking water and injections of an equal amount of $0.9 \% \mathrm{NaCl}$ at the same time that the modeling groups received the injections of $0.9 \% \mathrm{NaCl}$. The general performance of the mice was measured 
during CAC modeling, including body weight, diarrhea, colorectal bleeding, death, and tumor formation rate.

\section{Changes in colon in CAC model}

After the modeling, the specimens were put under anesthesia. The intestine was cut from the anus to the cecum, and after the feces were removed and put in phosphatebuffered saline (PBS) at $4{ }^{\circ} \mathrm{C}$, the intestine was flattened on the table. The length of the colon and the number of tumors were measured. The long diameter and short diameter of the tumor were measured with Vernier calipers to calculate the tumor volume (tumor volume $=1 / 2 \times$ long diameter $\times$ short diameter squared).

\section{HE staining}

The entire colon was washed with PBS and fixed in 4\% paraformaldehyde, and paraffin sections were made, followed by hematoxylin and eosin (HE) staining. Pathologists who were blinded to genotypes were asked to score the inflammation and tumor pathological changes. The scoring criteria was as Table 1.

\section{Immunohistochemistry}

The paraffin sections were deparaffinized in water, and the antigen retrieval was conducted by heating in a pressure cooker for $10 \mathrm{~min}$. The sections were cooled to room temperature and washed with $\mathrm{PBS}$, followed by the addition of $3 \%$ hydrogen peroxide, incubation for $10 \mathrm{~min}$, and washing. The sections were then blocked with blocking solution for $20 \mathrm{~min}$, the blocking solution was discarded, and the sections were added to 1:200 diluted primary antibody (TLR2: abcam, UK, 213676; Ki67: CST, USA, 12202), incubated overnight in a $4{ }^{\circ} \mathrm{C}$ refrigerator, and washed with PBS. Then, 1:100-diluted secondary antibodies were added dropwise on the sections and incubated for $30 \mathrm{~min}$ at room temperature, followed by a PBS wash. The sections were then added to streptavidin-Peroxidase (streptavidin-POD), incubated at room temperature for $30 \mathrm{~min}$, and washed with PBS. Chromogenic reaction was carried out using 3 '-diaminobenzidine $(\mathrm{DAB})$, and the process was observed under the microscope and terminated when the label turned the appropriate color. The DAB staining process usually took 3-5 min, followed by thorough washing in tap water, hematoxylin counterstaining for 2-3 min, full rinsing and differentiation in tap water, dehydration, clarification, and mounting in neutral resin.

\section{Cell lines}

Human CRC cell lines HCT116 and HT29 were purchased from American Type Culture Collection (ATCC; Virginia, USA), passaged within 6 months of thawing, and cultured in McCoy's 5A medium supplemented with $10 \%$ fetal bovine serum and 1\% streptomycin (Gibco, USA) in a sterile $37^{\circ} \mathrm{C}$ incubator with $5 \% \mathrm{CO}_{2}$.

\section{Cell transfection}

According to the experimental requirements, the cells in the logarithmic growth phase were counted, plated, and incubated overnight, followed by switching the medium to the infection medium. The optimal amount of lentivirus according to a multiplicity of infection $(\mathrm{MOI})=30$ (uninfected control group: no virus; negative control group: RNAi; gene knockdown group: TLR2-RNAi) and $4 \%$ transfection reagent (Genechem Group, Shanghai) were added for infection to knock down the TLR2 gene.

Table 1 Pathological scoring criteria of HE staining in mouse colon

\begin{tabular}{|c|c|c|c|c|c|}
\hline \multirow[t]{2}{*}{ Score } & \multicolumn{3}{|l|}{ Inflammation severity } & \multicolumn{2}{|l|}{ Tumor pathological } \\
\hline & $\begin{array}{l}\text { Pattern of leukocyte } \\
\text { infiltration }\end{array}$ & $\begin{array}{l}\text { Degree of leukocyte } \\
\text { infiltration }\end{array}$ & $\begin{array}{l}\text { Number } \\
\text { of infiltrated } \\
\text { leukocytes }\end{array}$ & $\begin{array}{l}\text { Classification of lesion } \\
\text { severity }\end{array}$ & Histological typing \\
\hline 1 point & $\begin{array}{l}\text { Increased lymphoid aggrega- } \\
\text { tion }\end{array}$ & $\begin{array}{l}\text { Infiltration confined to the } \\
\text { mucosa }\end{array}$ & Small amount & $\begin{array}{l}\text { Intraepithelial neoplasia } \\
\text { (nuclear floating does not } \\
\text { exceed } 3 / 4 \text { of the total } \\
\text { epithelial height) }\end{array}$ & $\begin{array}{l}\text { Highly differentiated } \\
\text { adenocarcinoma (>95\% } \\
\text { duct formation) }\end{array}$ \\
\hline 2 point & $\begin{array}{l}\text { Cryptitis (neutrophils in the } \\
\text { intestinal crypt epithelium) }\end{array}$ & Infiltration in the submucosa & Medium & $\begin{array}{l}\text { Intramucosal carcinoma } \\
\text { (disrupted gland structures, } \\
\text { with a shared gland wall } \\
\text { and a sieve-like structure, } \\
\text { without penetrating the } \\
\text { mucosal muscle layer) }\end{array}$ & $\begin{array}{l}\text { Moderately differenti- } \\
\text { ated adenocarcinoma } \\
\text { (50-95\% duct formation) }\end{array}$ \\
\hline 3 point & $\begin{array}{l}\text { Crypt abscess (neutrophils } \\
\text { accumulate in the crypt } \\
\text { cavity, sometimes showing } \\
\text { crypt rupture)/ }\end{array}$ & Infiltration of the whole layer & Severe & $\begin{array}{l}\text { Tubular adenocarcinoma } \\
\text { (tumor cells penetrating } \\
\text { the mucosal muscle layer) }\end{array}$ & $\begin{array}{l}\text { Poorly differentiated } \\
\text { adenocarcinoma (0-49\% } \\
\text { duct formation) }\end{array}$ \\
\hline 4 point & & & & & Undifferentiated carcinoma \\
\hline
\end{tabular}


After incubation for approximately $12-16 \mathrm{~h}$, the medium was then replaced with conventional medium for further culture. The cells were observed to be in good condition, and when the cell infection efficiency was over $80 \%$, the lentivirus-infected cells were further screened by adding $1 \mu \mathrm{g} / \mathrm{mL}$ puromycin (Gibco, USA), and the downstream experiment was carried out after 7-10 more days of culture. Lentivirus carries FITC fluorescent label, and successfully infected cells show green fluorescence under a fluorescence microscope.

\section{Western blot}

After collecting cells in the above uninfected control group, negative control group, and gene knockdown group, the cells were lysed on ice using a lysis buffer containing phenylmethylsulfonyl fluoride (PMSF) for $30 \mathrm{~min}$, then centrifuged at $12,000 \mathrm{rpm}$ for $30 \mathrm{~min}$ at $4{ }^{\circ} \mathrm{C}$. The protein content in the supernatant was determined by the bicinchoninic acid (BCA) method to prepare protein samples with the same total protein content. After $10 \%$ sodium dodecyl sulfate-polyacrylamide gel electrophoresis, the samples were transferred to polyvinylidene fluoride membranes (Millipore, USA). The membranes were then blocked with $5 \%$ fat-free milk for $2 \mathrm{~h}$ at room temperature, followed by the addition of the primary antibody (TLR2: CST, USA, 12276S; GAPDH: CST, USA, 5174S; p-NF-k $\beta$ : Santa Cruz Biotechnology, USA, 135769; cyclin D1: CST, USA, 55506S; cyclin D3: CST, USA, 2936; $\beta$-tubulin: CST, USA, 2128S; $\beta$-actin: CST, USA, 3700S)at 1:1000 dilution and incubation at $4{ }^{\circ} \mathrm{C}$ overnight. The membranes were then washed with Trisbuffered saline with $0.1 \%$ Tween 20 (TBST) 3 times for $5 \mathrm{~min}$ per wash, followed by incubation for $2 \mathrm{~h}$ at room temperature with secondary antibody at 1:5000 dilution. The membrane was then washed $3 \times 5$ min with TBST. The protein bands were visualized using the enhanced chemiluminescence (ECL) solution (Azure Biosystems, USA) to detect the expression of protein.

\section{Cell counting Kit-8 (CCK-8)}

The abovementioned HCT116 (2000 cells/well in 96-well plates) and HT29 cells (5000 cells/well in 96-well plates) of the uninfected control group, negative control group, and gene knockdown group were seeded into 96-well plates, and 5 parallel wells were set for each group. Cells were incubated in a $37{ }^{\circ} \mathrm{C}$ incubator with $5 \% \mathrm{CO} 2$. At 0 , 24,48 , and $72 \mathrm{~h}$ after cell attachment, CCK- 8 solution (Dojindo Molecular Technologies, Japan) was added at a ratio of $10 \mu \mathrm{L} / 100 \mu \mathrm{L}$ per well. Cells were placed in a $37{ }^{\circ} \mathrm{C}$ incubator with $5 \% \mathrm{CO}_{2}$ and incubated for $1 \mathrm{~h}$. The absorbance (optical density) values of each group at a wavelength of $450 \mathrm{~nm}$ were measured using a microplate reader, and the growth curves were plotted.

\section{Fluorescence-activated cell sorting (FACS analysis)}

The abovementioned uninfected control group, negative control group, and gene knockdown group of cells were seeded in a 6 -well plate at $5 \times 105 /$ well and incubated for $48 \mathrm{~h}$, followed by cell collection. Cells were washed twice with precooled PBS and resuspended in $300 \mu$ precooled PBS. Subsequently, $700 \mu \mathrm{l}$ of precooled absolute ethanol was slowly added in drops and mixed well, followed by fixation at $4{ }^{\circ} \mathrm{C}$ overnight. The mixture was then centrifuged at $1000 \mathrm{rpm}$ for $5 \mathrm{~min}$, the supernatant was discarded, and the pellet was then washed with precooled PBS 2 times. The cells were resuspended in $500 \mu \mathrm{l}$ precooled PBS and added to $20 \mu \mathrm{l}$ of RNase A solution (BestBio, Shanghai), followed by incubation in a $37{ }^{\circ} \mathrm{C}$ water bath for $30 \mathrm{~min}$. Cells were then centrifuged again at $1000 \mathrm{rpm}$ for $5 \mathrm{~min}$, the supernatant was discarded, and the cells were resuspended in $500 \mu \mathrm{l}$ propidium iodide (PI) staining solution (BestBio, Shanghai), followed by staining at $4{ }^{\circ} \mathrm{C}$ for $30 \mathrm{~min}$ in the dark. FACS analysis was carried out according to standard procedures and analyzed by software of Novo Express 1.1.0.

\section{Statistical methods}

Statistical analysis was performed on experimental data using SPSS 25.0 statistical software. The measurement data are expressed as the mean $\pm \mathrm{SD}$. The independentsample $t$ test was used for comparisons between 2 groups. Analysis of variance (ANOVA) was used for comparisons between 3 or more groups. Fisher's least significant difference (LSD) test and the Student-Newman-Keuls multiple range (SNK) test were used for pairwise comparison within groups. A difference was considered statistically significant at $\mathrm{P}<0.05$.

\section{Results \\ General performance}

To verify the role of TLR2 in the CAC tumorigenesis process, we established a working CAC model (Fig. 1). The general performance of the mice is shown in Fig. 2. The body weight showed a trend of increasing during the entire experimental period. The NC, KC, NT and KT groups presented a descending order of weight gain rates. In each cycle of DSS, the body weight of the mice first increased briefly and then decreased. Compared with the NT group, the weight increase and decrease in the KT group were more severe, and the body weights of the NT group and the KT group were significantly lower than those of the NC group and the $\mathrm{KC}$ group at the late stage of DSS administration. The rates of mouse diarrhea and rectal hemorrhage were as shown in Fig. 2. In the 3 cycles of DSS administration, the total diarrhea and rectal bleeding durations were significantly increased in the NT group $(7.67 \pm 1.03$; 


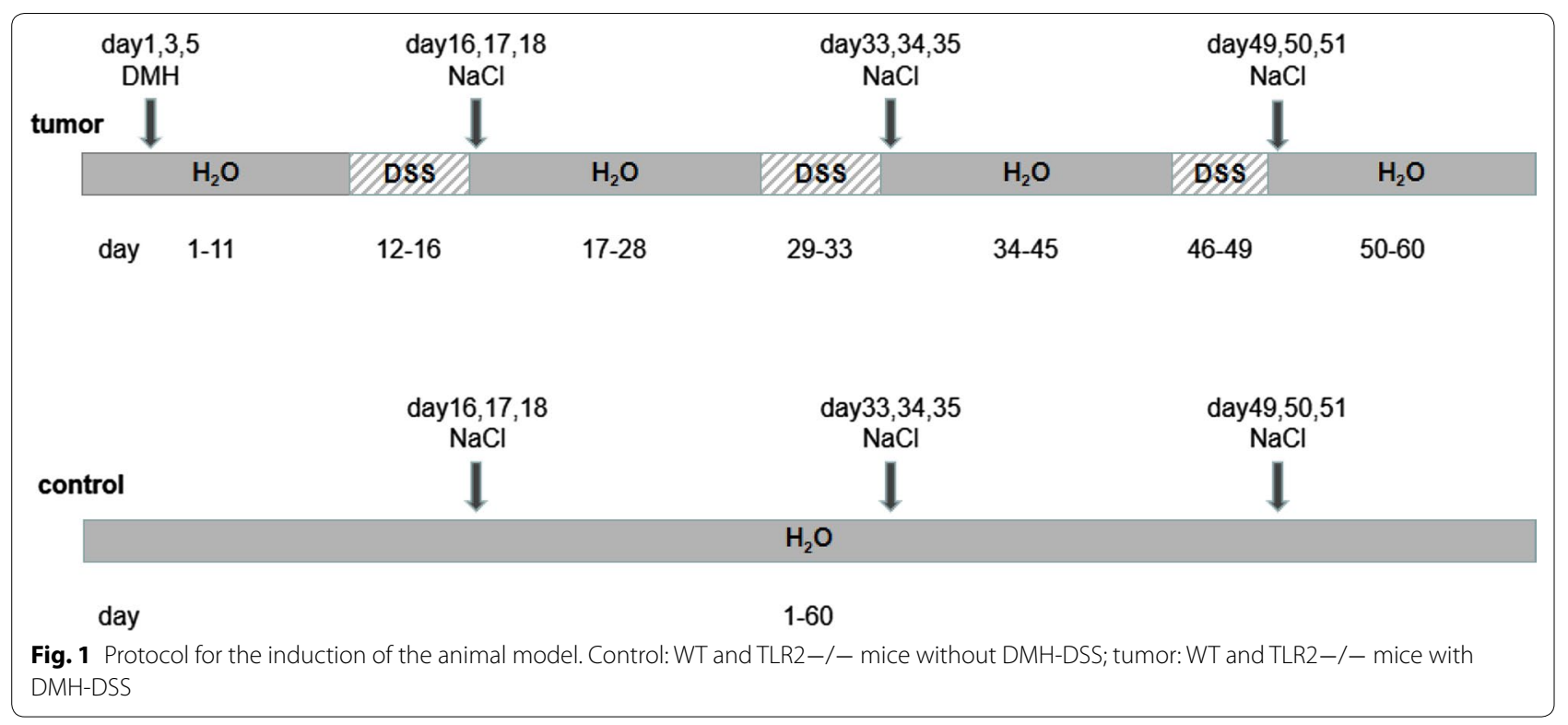
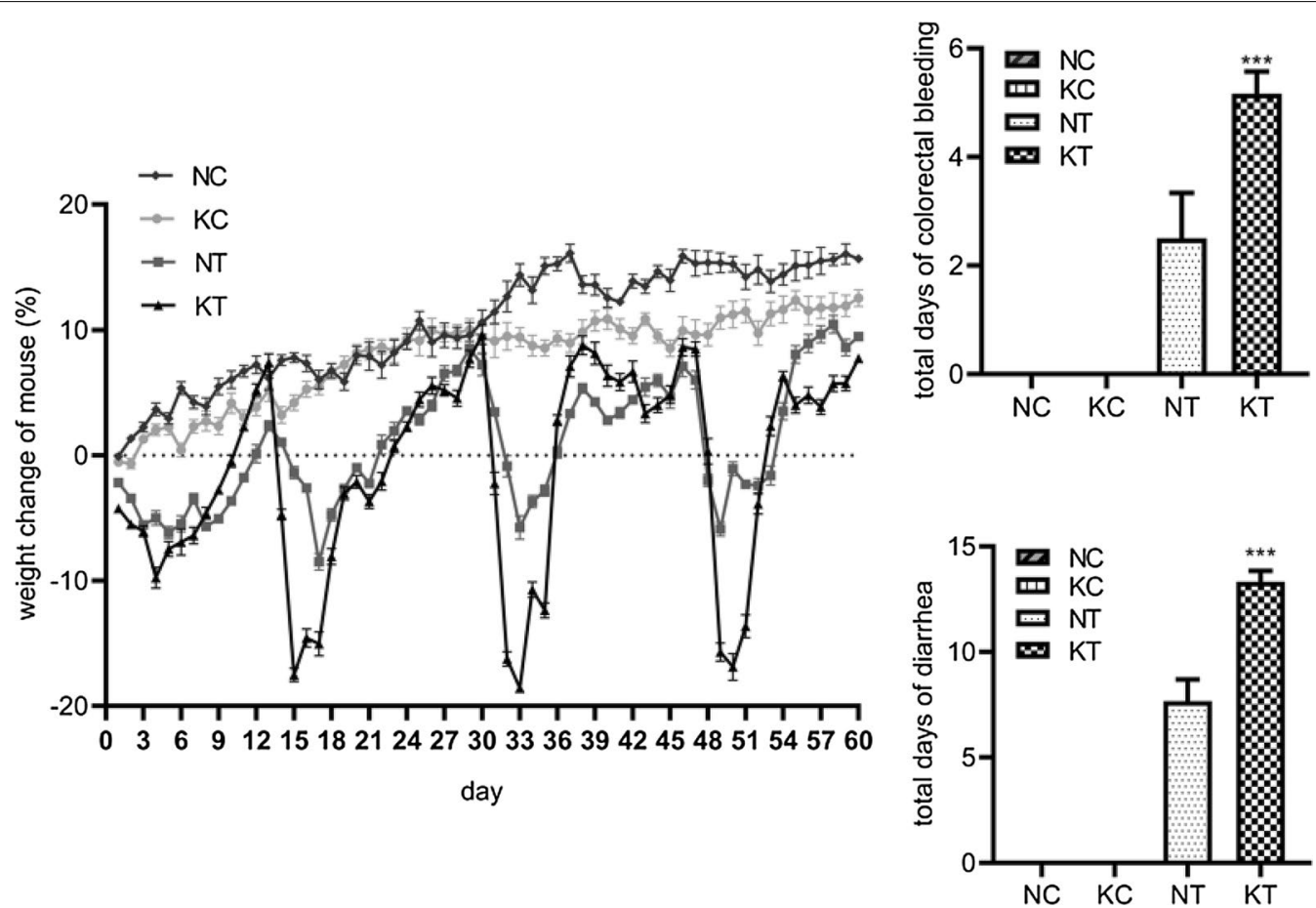

Fig. 2 General symptoms such as body weight, total days of diarrhea, and total days of bleeding. NC: WT without DMH-DSS; KC:TLR2-/- without DMH-DSS; NT: WT with DMH-DSS; KT: TLR2-/- with DMH-DSS. ***P<0.001, KT vs NT group $(n=6)$

$2.50 \pm 0.84)$ and $\mathrm{KT}$ group $(13.33 \pm 0.52 ; 5.17 \pm 0.41)$ compared to the NC group $(0.00 \pm 0.00 ; 0.00 \pm 0.00)$ and $\mathrm{KC}$ group $(0.00 \pm 0.00 ; 0.00 \pm 0.00)$, and the duration of diarrhea and duration of colorectal bleeding in the KT group were longer than in the NT group
$(\mathrm{P}<0.001)$. The mortality rate of $\mathrm{CAC}$ model mice was 0 , and the tumor formation rate of CAC model mice was $100 \%$. The above results suggest that DMH+DSS has a good modeling effect, TLR2 knockout can reduce the body weight of mice, and the CAC model also 
reduces the body weight of mice, while TLR2 gene knockout in the CAC model can lead to more severe changes in the body weight and more severe diarrhea and colorectal bleeding.

\section{Changes in gross morphology}

We observed changes in gross morphology after modeling, as shown in Fig. 3. The colorectal length shortening, number of colorectal tumors, and total tumor volume were significantly increased in the NT group $(2.67 \pm 0.79 ; 8.67 \pm 1.21 ; 52.48 \pm 14.97)$ and KT group $(1.62 \pm 0.73 ; 4.83 \pm 0.75 ; 13.77 \pm 6.18)$ compared to the NC group $(0.00 \pm 0.00 ; 0.00 \pm 0.00 ; 0.00 \pm 0.00)$ and KC group $(0.00 \pm 0.00 ; 0.00 \pm 0.00 ; 0.00 \pm 0.00)$, while the $\mathrm{KT}$ group showed a significant reduction compared to the NT group $(\mathrm{P}=0.038 ; \mathrm{P}=0.00 ; \mathrm{P}=0.001)$. These results suggest that knocking out the TLR2 gene can reduce the colorectal length shortening, tumor number, and total tumor volume and inhibit CAC growth.

\section{HE staining}

As shown in Fig. 4, the pathological scores of HE staining revealed that the inflammation degree score and the tumor pathological score significantly increased in the NT group $(7.50 \pm 0.84 ; 4.67 \pm 0.52)$ and the KT group $(4.50 \pm 1.22 ; 3.67 \pm 0.52)$ compared with the NC group $(0.00 \pm 0.00 ; 0.00 \pm 0.00)$ and the KC group $(0.00 \pm 0.00$; $0.00 \pm 0.00$ ), while those in the KT group significantly decreased compared to the NT group $(\mathrm{P}=0.001$; $\mathrm{P}=0.007$ ). The results suggest that knocking out the TLR2 gene can reduce the CAC pathological score and reduce the severity of the tumor.

\section{Immunohistochemistry}

The immunohistochemical results (Fig. 5; Table 2) showed that TLR2 was localized on the cell membrane of the colorectal epithelium in the $\mathrm{NC}$ group and of the colorectal tumors in the NT group, and the positive rates of the NT group $(72.63 \% \pm 4.20 \%)$ and NC group $(56.57 \% \pm 5.64 \%)$ were higher than those of the KC group $(4.73 \% \pm 0.82 \%)$ and the KT group $(5.10 \% \pm 0.65 \%)$,

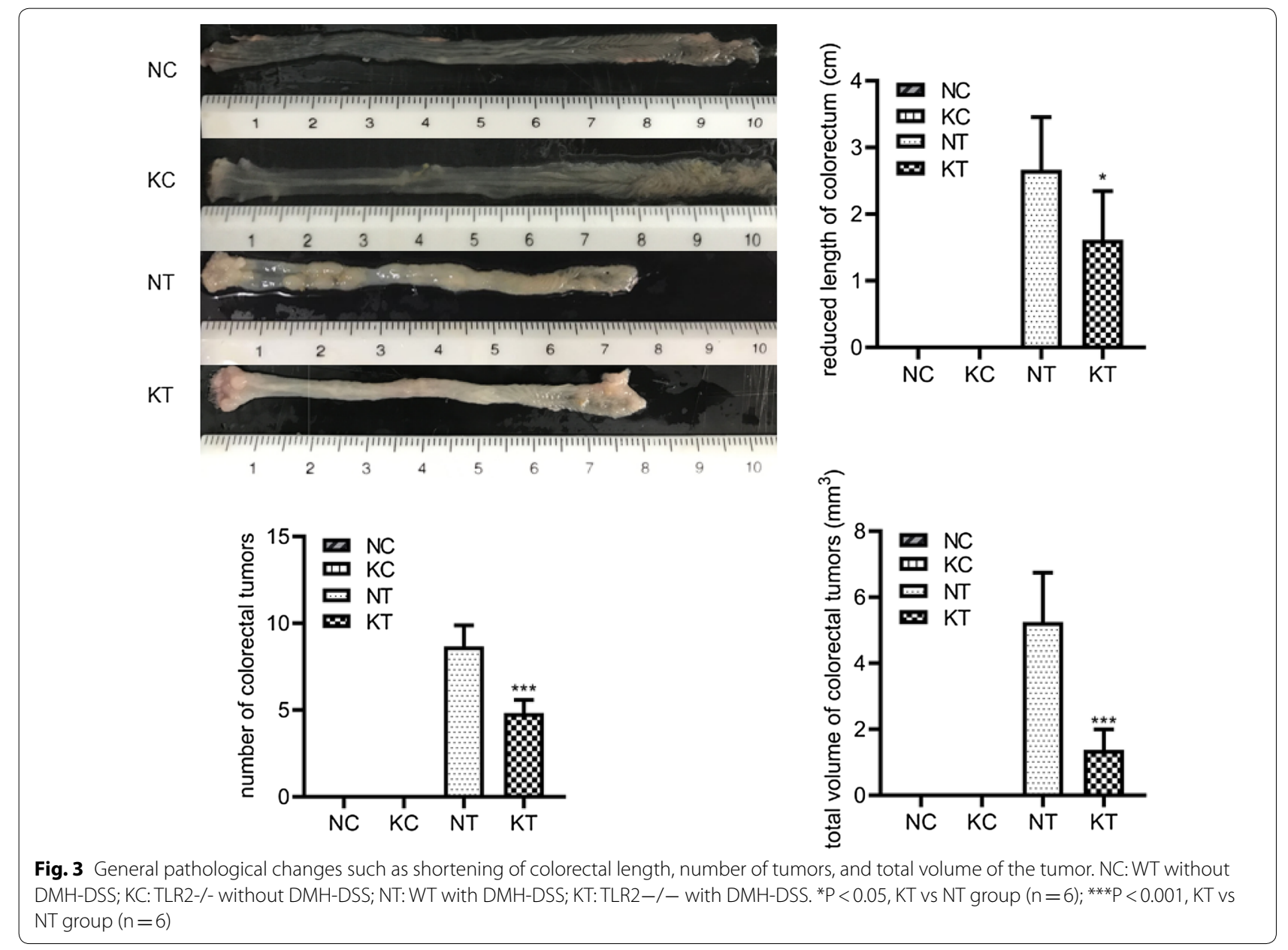




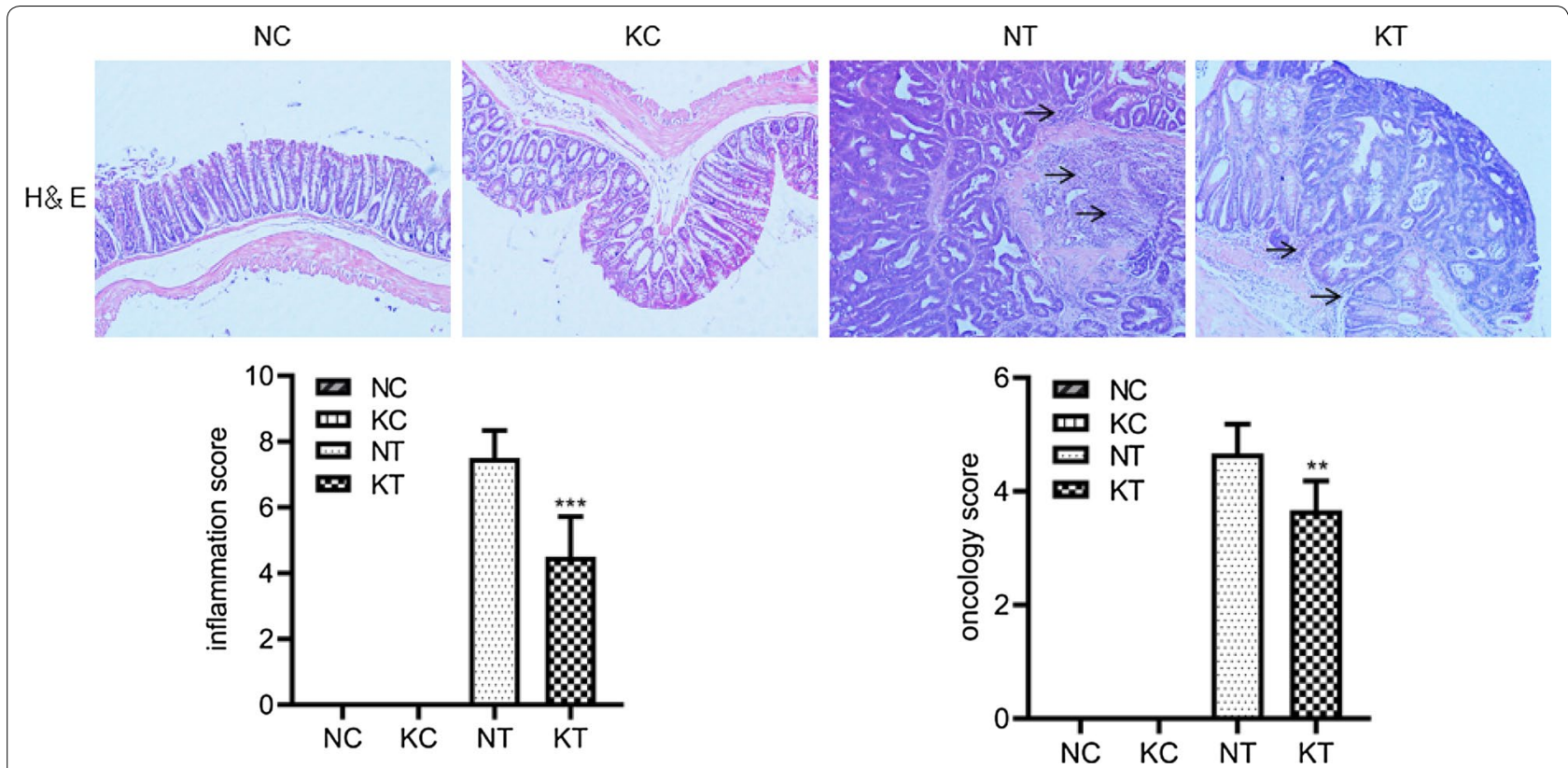

Fig. 4 Mouse colorectal HE staining (microscope $\times 100$ ) and tumor pathological score. NC: WT without DMH-DSS; KC: TLR2-/- without DMH-DSS; NT: WT with DMH-DSS; KT:TLR2-/ - with DMH-DSS. Blue represents the nucleus and pink represents the cytoplasm. These arrows represent infiltrating leukocytes. ${ }^{* *} \mathrm{P}<0.001$, KT vs NT group $(n=6) ;{ }^{*} \mathrm{P}<0.01, \mathrm{KT}$ vs NT group $(n=6)$

while the positive rate of the NT group was higher than that of the NC group $(\mathrm{P}<0.001)$. Ki67 was localized in the nucleus of colorectal tumors in the NT group and the KT group. The Ki67-positive rates of the NT group $(66.03 \% \pm 9.21 \%)$ and KT group $(39.53 \% \pm 3.54 \%)$ were significantly higher than those of the NC group $(3.30 \% \pm 0.27 \%)$ and $\mathrm{KC}$ group $(3.87 \% \pm 0.41 \%)$, and the positive rate of the KT group was significantly reduced compared to that of the NT group $(\mathrm{P}<0.001)$. These findings suggest that TLR2 is highly expressed in CAC and knocking out TLR2 can inhibit CAC proliferation.

\section{Cell transfection}

In the process of constructing a strain with stable lentivirus infection, the results of transfection efficiency under the fluorescence microscope (Fig. 6) showed that the transfection efficiency rates of HCT116 and HT29 negative control groups and gene knockdown groups reached more than $80 \%$. There was no difference in transfection efficiency $(P>0.05)$, and the cells could be used to verify the expression of TLR2 protein.

\section{Western blot}

The results of Western blotting (Fig. 7) showed that compared with the uninfected control group $(0.98 \pm 0.06$; $1.01 \pm 0.06)$ and the negative control group $(0.94 \pm 0.03$; $0.96 \pm 0.12)$, the expression levels of TLR2 protein in HCT116 and HT29 cells were significantly decreased in the gene knockdown group $(0.33 \pm 0.09 ; 0.52 \pm 0.03)$ $(\mathrm{P}<0.001)$. The above results indicated that the lentivirus carrying TLR2-RNAi had a significant downregulation effect on the expression of TLR2 protein in HT29 and HCT116 cells. The results of Western blotting (Fig. 8; Table 3) showed that compared with the uninfected control group and the negative control group, the protein expression levels of $\mathrm{p}-\mathrm{NF}-\mathrm{k} \beta$, cyclin D1 and cyclin D3 in HCT116 and HT29 cells were significantly decreased in the gene knockdown group $(\mathrm{P}<0.01)$.

\section{CCK-8}

The results of the CCK-8 assay showed (Fig. 9) that the proliferation rates of HCT116 and HT29 cells in the gene knockdown groups were significantly lower at 24,48 , and $72 \mathrm{~h}$ than in the uninfected control group and the negative control group $(\mathrm{P}<0.05)$. These results suggest that knockdown of TLR2 gene expression can significantly inhibit sCRC cell proliferation.

\section{FACS analysis}

The results of FACS analysis (Fig. 10; Table 4) showed that the percentages of $\mathrm{S}$ phase+G2 phase cells in HCT116 and HT29 cells in the knockdown groups were significantly lower than in the uninfected control group and the negative control group $(\mathrm{P}<0.05)$, while the percentages of cells in G1 phase were significantly increased $(P<0.05)$. This suggests that knockdown of 


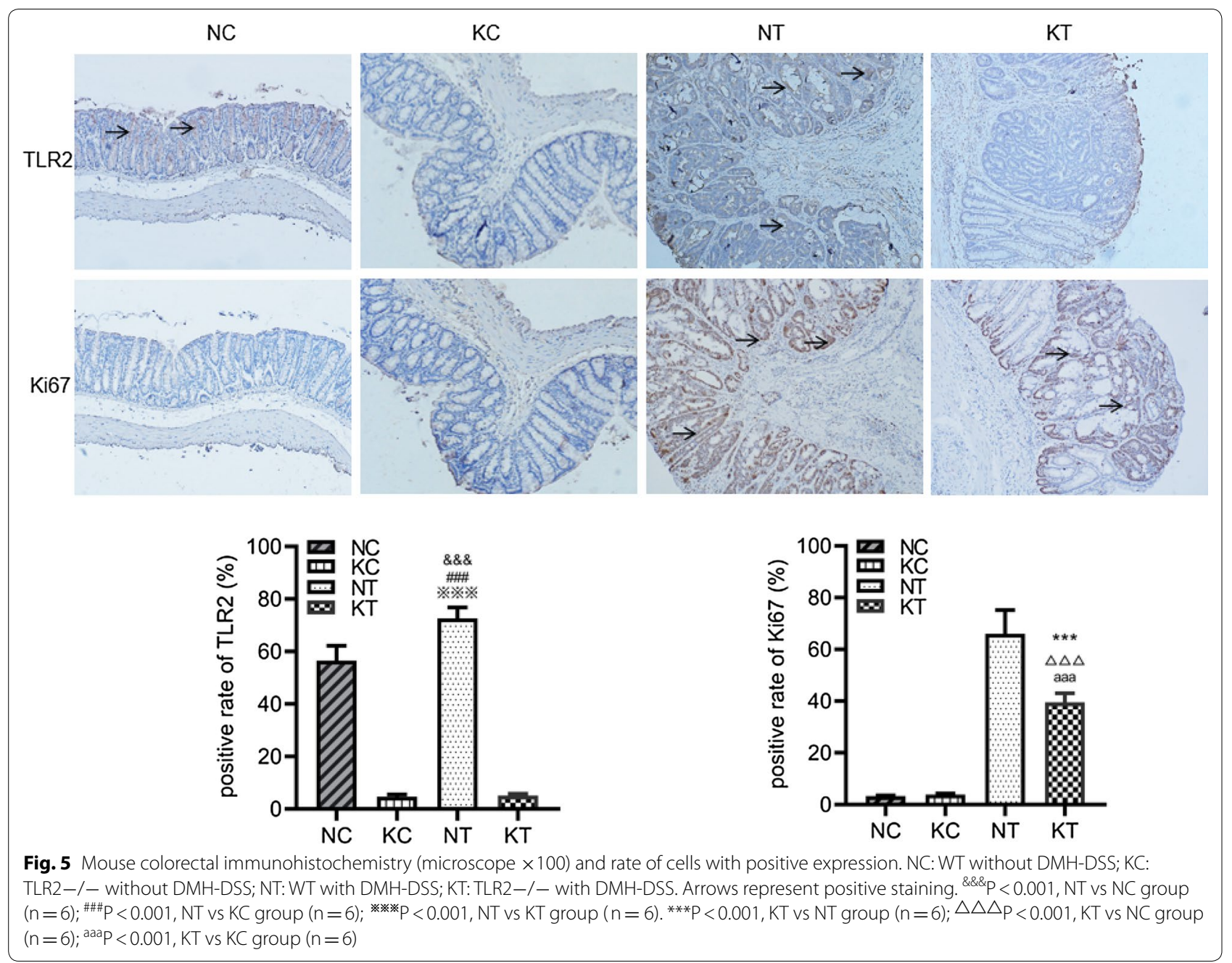

Table 2 Percentage of positive cells in various groups of colon detected by Immunohistochemistry method ( $\mathbf{n}=$ 6, $\overline{\mathrm{x}} \pm \mathrm{s})$

\begin{tabular}{lcl}
\hline Group & $\begin{array}{l}\text { Percentage of TLR2 positive } \\
\text { cells }\end{array}$ & $\begin{array}{l}\text { Percentage } \\
\text { of Ki67 positive } \\
\text { cells }\end{array}$ \\
\hline NC & $56.57 \% \pm 5.64 \%$ & $3.30 \% \pm 0.27 \%$ \\
KC & $4.73 \% \pm 0.82 \%$ & $3.87 \% \pm 0.41 \%$ \\
NT & $72.63 \% \pm 4.20 \%^{* * *}$ & $66.03 \% \pm 9.21 \%$ \\
KT & $5.10 \% \pm 0.65 \%$ & $39.53 \% \pm 3.54 \% \Delta \Delta \Delta$ \\
\hline
\end{tabular}

${ }^{* * *} P<0.001$ compared NC group; ${ }^{\Delta \Delta} P<0.001$ compared with NT group

TLR2 gene expression can inhibit the proliferation of colorectal cancer cells, leading to cell cycle arrest in the G1 phase and thereby significantly inhibiting the sCRC cell cycle.

\section{Discussion}

TLR2 is a key regulator of the innate immune response and has been shown to play an important role in cancer. In previous studies, TLR2 was found to be expressed at a high level in most patients with gastric cancer, and high expression of TLR2 was associated with proliferative genes and indicated a poor prognosis, while other studies have also suggested that TLR2 promotes the development of gastric cancer $[15,16]$. In pancreatic cancer and breast cancer, TLR2 promotes the proliferation of tumor cells $[17,18]$. In mantle cell lymphoma, TLR2 promotes the proliferation of tumor cells, and it can also inhibit the cell cycle progression of mantle cell lymphoma, leading to G1 phase arrest [19]. Colorectal cancer tissues usually have higher TLR2 gene expression levels than normal colorectal mucosa from the same patient, and activation of TLR2 and TLR4 in previous studies of colorectal cancer has also been shown to promote tumor cell proliferation $[9,10,14,20]$. Our study demonstrates that knocking out the TLR2 gene inhibits CAC growth, reduces tumor 


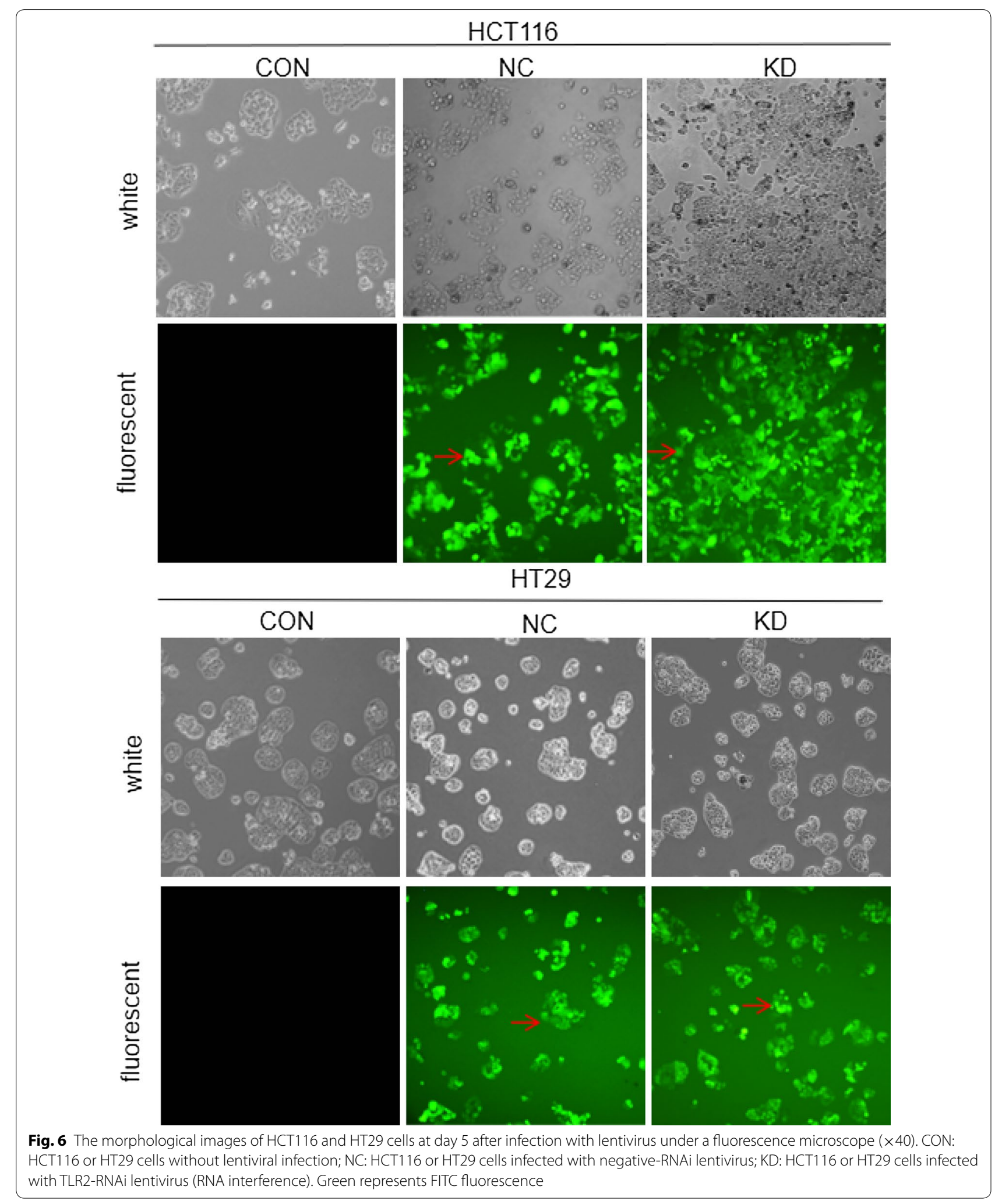




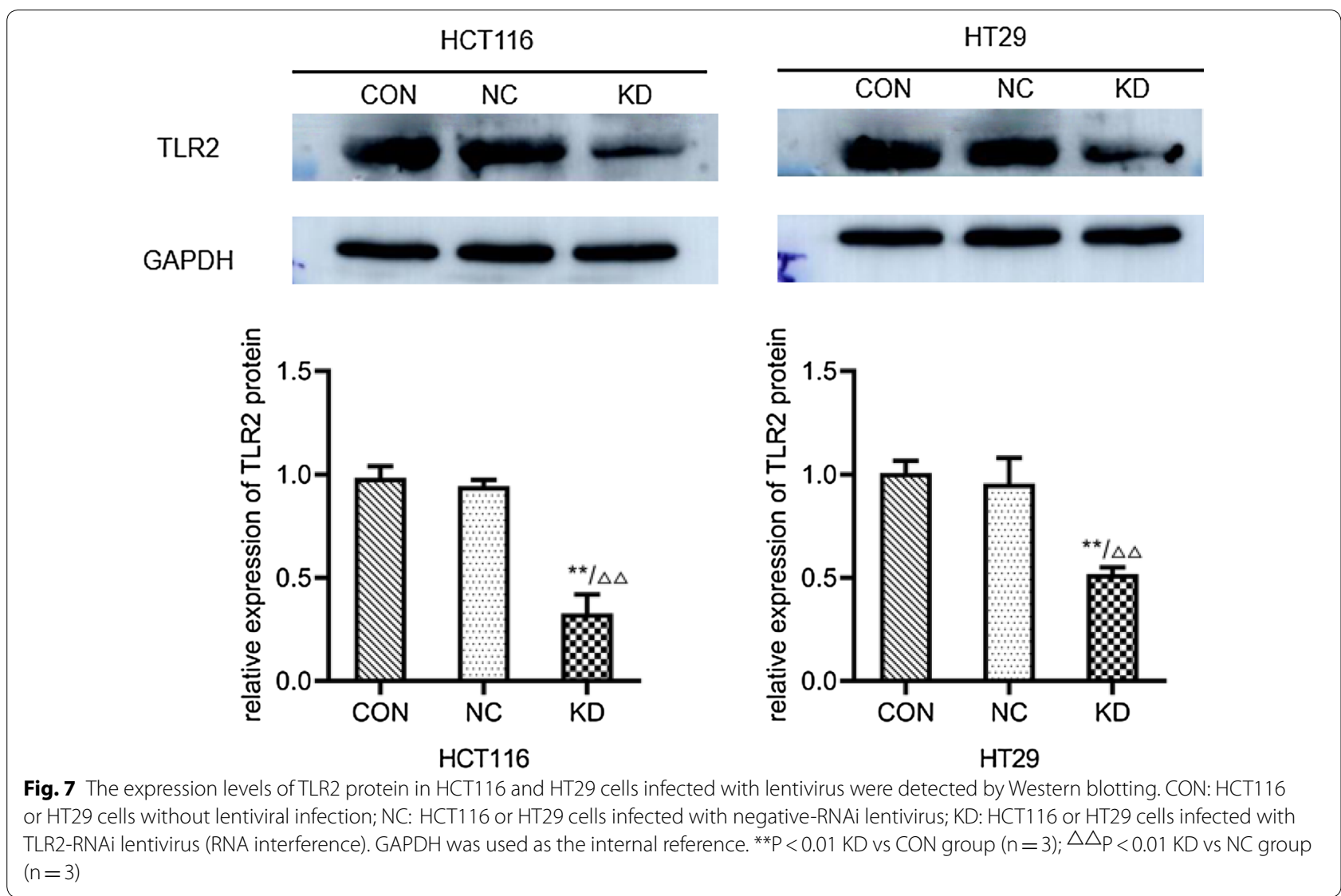
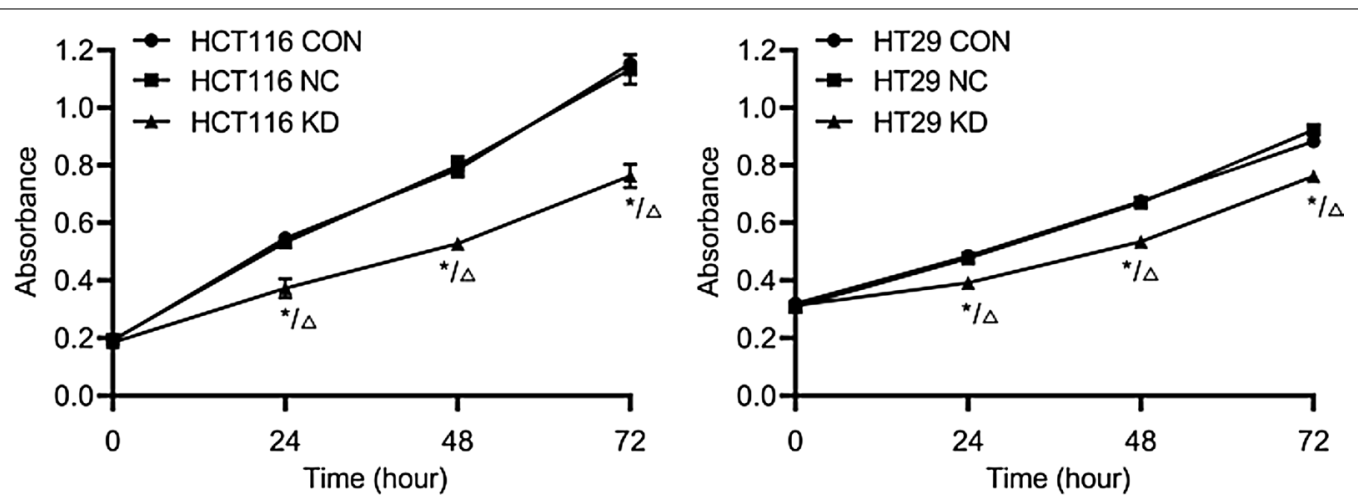

Fig. 8 The expression levels of proteins in HCT116 and HT29 cells in various groups detected by Western blotting method. CON: HCT116 or HT29 cells without lentiviral infection; NC: HCT116 or HT29 cells infected with negative-RNAi lentivirus; KD: HCT116 or HT29 cells infected with TLR2-RNAi lentivirus (RNA interference). GAPDH was used as the internal reference. ${ }^{* *} \mathrm{P}<0.01 \mathrm{KD}$ vs CON group $(n=3) ; \triangle \mathrm{P}<0.01 \mathrm{KD}$ vs NC group ( $n=3$ )

severity, and reduces tumor proliferation and that TLR2 is highly expressed in CAC, consistent with the reported effects of TLR2 on tumors. In the cellular experiment, we used the CCK-8 assay to find that knockdown of TLR2 can inhibit the proliferation of sCRC cells, and we also found that it inhibited the cell cycle progression of sCRC cells, leading to G1 phase arrest.
In CRC, CAC has a molecular mechanism that is not identical to that of sCRC. The time and frequency of gene mutations in CAC appear to be different from those in sCRC. The frequency of aneuploidy in CAC is higher than in $\mathrm{SCRC}$, and the total methylation level of CAC is lower than in sCRC. Different molecular changes in CAC and sCRC play different roles in tumor repair, 
Table 3 Expressions of proteins in HCT116 and HT29 cells in various groups detected by Western blotting method ( $\mathrm{n}=3$, $\overline{\mathbf{x}} \pm \mathbf{s})$

\begin{tabular}{|c|c|c|c|c|c|c|}
\hline \multirow[t]{2}{*}{ Group } & \multicolumn{3}{|c|}{ Expression of protein of HCT116 cells } & \multicolumn{3}{|c|}{ Expression of protein of HT29 cells } \\
\hline & p-NF-k $\beta$ & cyclin D1 & cyclin D3 & p-NF-k $\beta$ & cyclin D1 & cyclin D3 \\
\hline Non-infection control & $1.06 \pm 0.10$ & $0.89 \pm 0.02$ & $1.19 \pm 0.12$ & $1.07 \pm 0.14$ & $1.03 \pm 0.09$ & $1.19 \pm 0.05$ \\
\hline Negative control & $1.02 \pm 0.24$ & $0.84 \pm 0.07$ & $1.15 \pm 0.19$ & $0.90 \pm 0.12$ & $0.87 \pm 0.10$ & $1.06 \pm 0.09$ \\
\hline TLR2-RNAi & $0.29 \pm 0.15^{* * \Delta \Delta}$ & $0.35 \pm 0.08^{* * \Delta \Delta}$ & $0.57 \pm 0.10^{* * \Delta \Delta}$ & $0.55 \pm 0.11^{* * \Delta \Delta}$ & $0.44 \pm 0.10^{* * \Delta \triangle}$ & $0.53 \pm 0.13^{*}$ \\
\hline
\end{tabular}

** $P<0.01$ compared with non-infection control group; ${ }^{\Delta \Delta} P<0.01$ compared with Negative control group
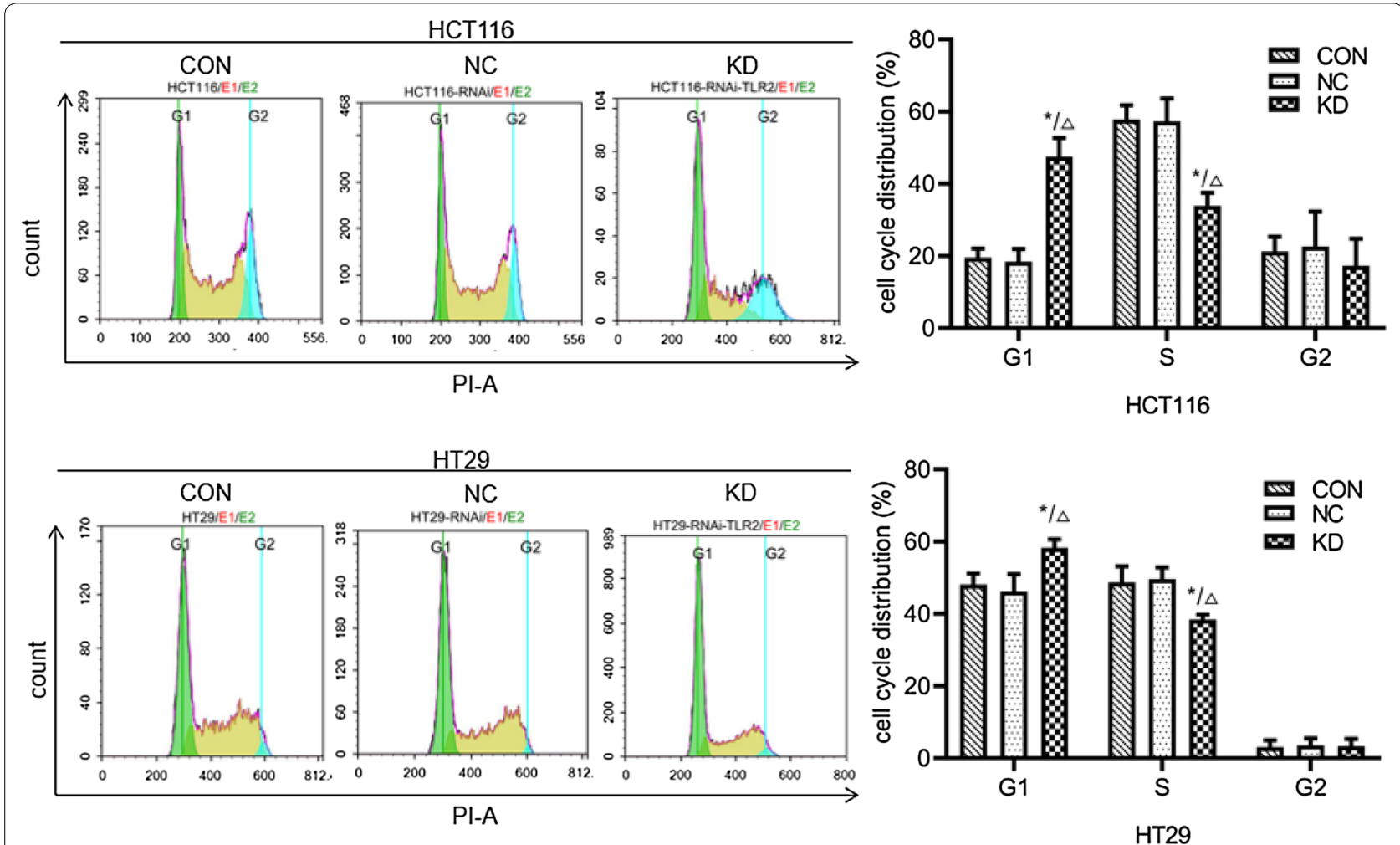

Fig. 9 The effect of TLR2 gene knockdown on the proliferation of HCT116 and HT29 cells was determined by CCK-8 assay. CON: HCT116 or HT29 cells without lentiviral infection; NC: HCT116 or HT29 cells infected with negative-RNAi lentivirus; KD: HCT116 or HT29 cells infected with TLR2-RNAi lentivirus (RNA interference). ${ }^{*} \mathrm{P}<0.05 \mathrm{KD}$ vs CON group $(n=3) ; \triangle p<0.05 \mathrm{KD}$ vs NC group $(n=3)$

immune response, cellular metabolism, and interactions with microbiota during tumorigenesis. These molecules (immunoglobulin light chain V-region locus1 (Igl-V1), galectin 2 (LGALS2), Nur77 dependent gene-1 (NDG1),et al.) play different roles in DNA damage repair, immune and inflammatory responses, cell cycle, apoptosis, and cell metabolism [8, 21, 22]. This study demonstrates that TLR2 plays a common role in tumor proliferation in CAC and sCRC.

Many different drug regimens induce the CAC model, which have different rates of tumor formation and different times of tumor onset. Azoxymethane
$(\mathrm{AOM})+\mathrm{DSS}, \mathrm{DMH}+\mathrm{DSS}, \mathrm{AOM} / \mathrm{DMH}+$ trinitrobenzenesulfonic acid are the 3 most commonly used modeling methods [23-25]. Although DSS + AOM is widely used, AOM is expensive and highly toxic and has high transportation requirements. We therefore have chosen DMH + DSS, which has the same modeling mechanism as DSS + AOM. Based on our previous studies, we adjusted the DMH dose and gave rehydration treatment, thus obtaining the modeling results of $100 \%$ tumor formation rate and 0 fatality rate. In our study, the results of animal experiments in terms of body weight and clinical symptoms were not completely 

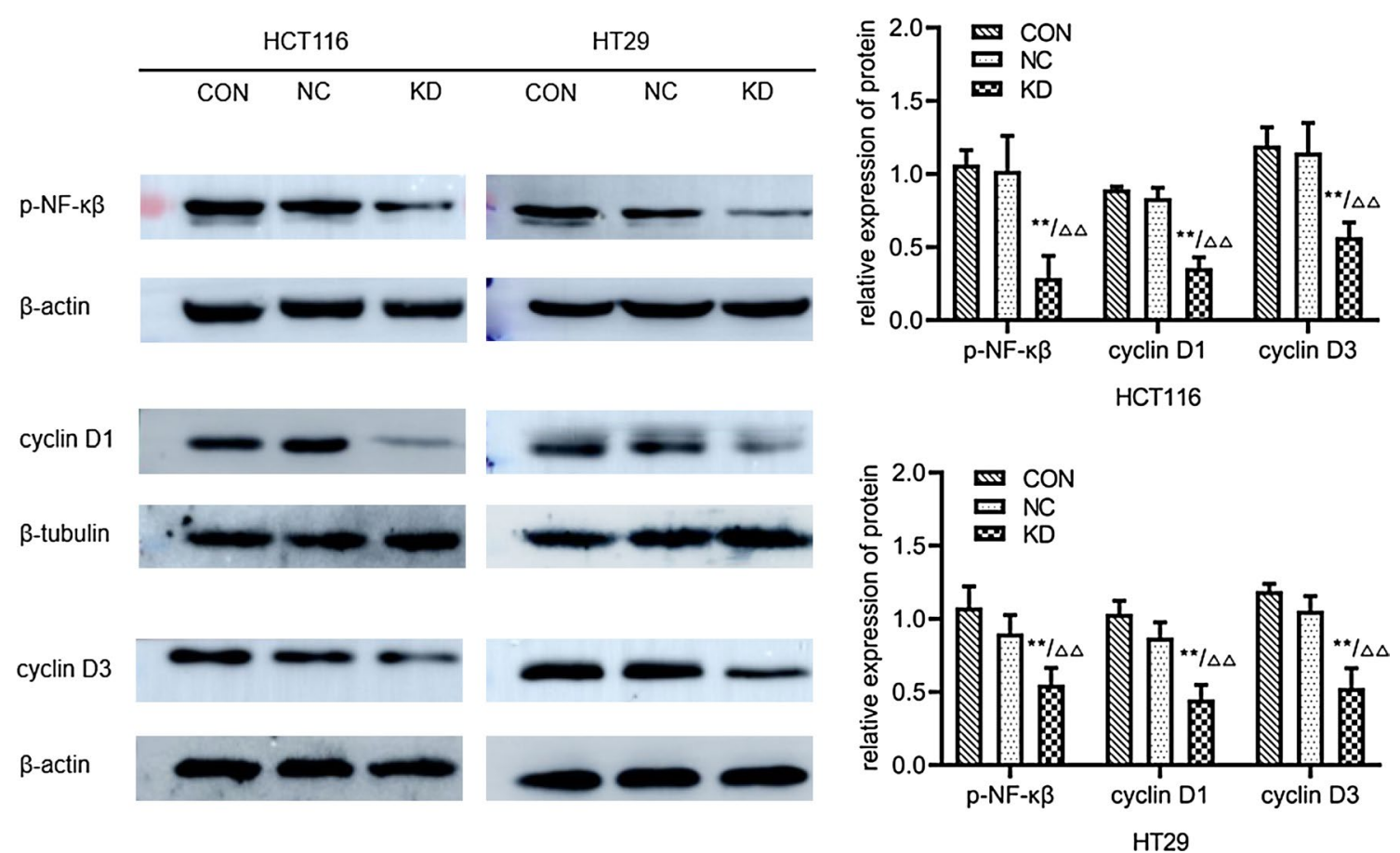

Fig. 10 The effect of TLR2 gene knockdown on the cell cycle of HCT116 and HT29 cells was determined by FACS analysis. CON: HCT116 or HT29 cells without lentiviral infection; NC: HCT116 or HT29 cells infected with negative-RNAi lentivirus; KD: HCT116 or HT29 cells infected with TLR2-RNAi lentivirus (RNA interference). ${ }^{*} P<0.05 K D$ vs CON group $(n=3) ; \triangle P<0.05 K D$ vs NC group $(n=3)$

Table 4 Cell cycle of HCT116 and HT29 cells in various groups detected by flow cytometry $(n=3, \bar{x} \pm s)$

\begin{tabular}{|c|c|c|c|c|c|c|}
\hline \multirow[t]{2}{*}{ Group } & \multicolumn{3}{|c|}{ Cell cycle of HCT116 cells (\%) } & \multicolumn{3}{|c|}{ Cell cycle of HT29 cells (\%) } \\
\hline & G1 & $\mathrm{S}$ & G2 & G1 & $S$ & G2 \\
\hline Non-infection control & $19.54 \pm 2.51$ & $57.86 \pm 3.90$ & $21.24 \pm 4.12$ & $48.08 \pm 3.03$ & $48.67 \pm 4.49$ & $3.07 \pm 1.91$ \\
\hline Negative control & $18.40 \pm 3.51$ & $57.27 \pm 6.37$ & $22.65 \pm 9.68$ & $46.21 \pm 4.74$ & $49.64 \pm 3.16$ & $3.58 \pm 1.94$ \\
\hline TLR2-RNAi & $47.52 \pm 5.18^{* \Delta}$ & $33.92 \pm 3.60^{* \Delta}$ & $17.33 \pm 7.44$ & $58.28 \pm 2.31^{* \Delta}$ & $38.40 \pm 1.35^{* \Delta}$ & $3.28 \pm 2.11$ \\
\hline
\end{tabular}

${ }^{*} P<0.05$ compared with non-infection control group; ${ }^{\Delta} P<0.05$ compared with Negative control group

consistent with the pathological results. It is possible that TLR2 has a greater impact on body weight, that it interacts with the modeling drug, and that changes in body weight and related symptoms do not directly reflect the severity of the cancer [26].

\section{Conclusion}

Thus, we demonstrated that Knockout and knockdown of TLR2 can inhibit the proliferation of CAC and sCRC through animal experiments and cellular experiments, which suggests that TLR2 plays a key role in CRC and may provide promising new targets for CRC therapy.

\section{Abbreviations}

CAC: Colitis-associated cancer; IBD: Inflammatory bowel disease; CRC: Colorectal cancer; sCRC: Sporadic colorectal cancer; TLRs: Toll-like receptors; $\mathrm{DMH}$ : 1,2-Dimethylhydrazine; DSS: Dextran sodium sulfate; AOM: Azoxymethane; PMSF: Phenylmethylsulfonyl fluoride; BCA: Bicinchoninic acid; ECL: Chemiluminescence; PI: Propidium iodide; Igl-V1: Immunoglobulin light chain V-region locus1; LGALS2: Galectin 2; NDG1: Nur77 dependent gene-1.

\section{Acknowledgements}

We wish to express our gratitude for the selfless help of Professors Song Bing, Ma Mingxiao, Tan Huibing, and Zheng Huachuan and the support, understanding, and companionship of Zhang Huiling and Liu Lili.

\section{Authors' contributions}

SM performed the in vitro and vivo assays. The majority of the data was accumulated YJL and ZXZ. Additional data was provided by ZJ and HHN. JL was responsible for supervising the project and giving intellectual input. SM wrote 
the manuscript and all authors reviewed it. All authors read and approved the final manuscript.

\section{Funding}

This research was supported by Grants obtained from Natural Science Foundation of Science and Technology Department of Liaoning Province (20170540391).

\section{Availability of data and materials}

The datasets generated and analysed during the current study are available from the corresponding author on reasonable request.

\section{Ethics approval and consent to participate}

All applicable international, national, and/or institutional guidelines for the care and use of animals were followed.

\section{Consent for publication}

Not applicable.

\section{Competing interests}

The authors declare that they have no competing interests.

\section{Author details}

1 Department of Gastroenterology, The First Affiliated Hospital of Jinzhou Medical University, No. 2, Section 5 Renmin Street, Guta District, Jinzhou City 121001, Liaoning Province, China. ${ }^{2}$ Jinzhou Medical University, No. 40, Section 3, Songpo Road, Linghe District, Jinzhou City 121001, Liaoning Province, China. ${ }^{3}$ Jinzhou No. 2 Hospital, No. 2, Section 6, Nanjing Road, Linghe District, Jinzhou City 121001, Liaoning Province, China.

Received: 17 December 2019 Accepted: 23 March 2020 Published online: 30 March 2020

\section{References}

1. Torre LA, Bray F, Siegel RL, Ferlay J, Lortet-Tieulent J, Jemal A. Global cancer statistics, 2012. CA Cancer J Clin. 2015;65(2):87-108.

2. Arnold M, Sierra MS, Laversanne M, Soerjomataram I, Jemal A, Bray F. Global patterns and trends in colorectal cancer incidence and mortality. Gut. 2017;66(4):683-91.

3. Aggarwal BB, Vijayalekshmi RV, Sung B. Targeting inflammatory pathways for prevention and therapy of cancer: short-term friend, long-term foe. Clin Cancer Res. 2009:15(2):425-30.

4. Kanneganti M, Mino-Kenudson M, Mizoguchi E. Animal models of colitisassociated carcinogenesis. J Biomed Biotechnol. 2011;2011:342637.

5. Yaeger R, Shah MA, Miller VA, et al. Genomic alterations observed in colitis-associated cancers are distinct from those found in sporadic colorectal cancers and vary by type of inflammatory bowel disease. Gastroenterology. 2016;151(2):278-87.

6. Waldner MJ, Neurath MF. Colitis-associated cancer: the role of T cells in tumor development. Semin Immunopathol. 2009;31(2):249-56.

7. Colotta F, Allavena P, Sica A, Garlanda C, Mantovani A. Cancer-related inflammation, the seventh hallmark of cancer: links to genetic instability. Carcinogenesis. 2009;30(7):1073-81.

8. Neufert C, Becker C, Türeci Ö, et al. Tumor fibroblast-derived epiregulin promotes growth of colitis-associated neoplasms through ERK. J Clin Invest. 2013;123(4):1428-43.
9. Liu YD, Ji CB, Li SB, et al. Toll-like receptor 2 stimulation promotes colorectal cancer cell growth via PI3K/Akt and NF-KB signaling pathways. Int Immunopharmacol. 2018:59:375-83.

10. Lu CC, Kuo HC, Wang FS, Jou MH, Lee KC, Chuang JH. Upregulation of TLRs and IL-6 as a marker in human colorectal cancer. Int J Mol Sci. 2014;16(1):159-77.

11. Medvedev AE. Toll-like receptor polymorphisms, inflammatory and infectious diseases, allergies, and cancer. J Interferon Cytokine Res. 2013;33(9):467-84

12. Liu Y, Yin H, Zhao M, Lu Q. TLR2 and TLR4 in autoimmune diseases: a comprehensive review. Clin Rev Allergy Immunol. 2014:47(2):136-47.

13. Hernandez C, Huebener P, Schwabe RF. Damage-associated molecular patterns in cancer: a double-edged sword. Oncogene. 2016:35(46):5931-41.

14. Proença MA, de Oliveira JG, Cadamuro AC, et al. TLR2 and TLR4 polymorphisms influence mRNA and protein expression in colorectal cancer. World J Gastroenterol. 2015;21(25):7730-41.

15. Kennedy $\mathrm{CL}$, Najdovska $\mathrm{M}$, Tye $\mathrm{H}$, et al. Differential role of MyD88 and Mal/TIRAP in TLR2-mediated gastric tumourigenesis. Oncogene. 2014:33(19):2540-6.

16. West AC, Tang K, Tye $H$, et al. Identification of a TLR2-regulated gene signature associated with tumor cell growth in gastric cancer. Oncogene. 2017:36(36):5134-44

17. Grimmig T, Moench R, Kreckel J, et al. Toll like receptor 2, 4, and 9 signaling promotes autoregulative tumor cell growth and VEGF/PDGF expression in human pancreatic cancer. Int J Mol Sci. 2016;17(12):e2060.

18. Scheeren FA, Kuo AH, van Weele $\sqcup$, et al. A cell-intrinsic role for TLR2MYD88 in intestinal and breast epithelia and oncogenesis. Nat Cell Biol. 2014:16(12):1238-48

19. Mastorci K, Muraro E, Pasini E, et al. Toll-like receptor $1 / 2$ and 5 ligands enhance the expression of cyclin D1 and D3 and induce proliferation in mantle cell lymphoma. PLOS ONE. 2016;11(4):e0153823.

20. Semlali A, Reddy PN, Arafah M, et al. Expression and polymorphism of toll-like receptor 4 and effect on NF-KB mediated inflammation in colon cancer patients. PLoS ONE. 2016;11(1):e0146333.

21. Gerling M, Meyer KF, Fuchs K, et al. High frequency of aneuploidy defines ulcerative colitis-associated carcinomas. Ann Surg. 2010;252(1):74-83.

22. Olaru AV, Cheng Y, Agarwal $R$, et al. Unique patterns of $C p G$ island methylation in inflammatory bowel disease-associated colorectal cancers. Inflamm Bowel Dis. 2012:18(4):641-8.

23. Kohno H, Suzuki R, Sugie S, Tanaka T. Beta-Catenin mutations in a mouse model of inflammation-related colon carcinogenesis induced by 1,2-dimethylhydrazine and dextran sodium sulfate. Cancer Sci. 2005;96(2):69-76.

24. Thaker Al, Shaker A, Rao MS, Ciorba MA. Modeling colitis-associated cancer with azoxymethane (AOM) and dextran sulfate sodium (DSS). J Vis Exp. 2012;67:4100.

25. Sugihara Y, Zuo X, Takata T, et al. Inhibition of DMH-DSS-induced colorectal cancer by liposomal bovine lactoferrin in rats. Oncol Lett. 2017; 14(5):5688-94.

26. Himes RW, Smith CW. Tlr2 is critical for diet-induced metabolic syndrome in a murine model. FASEB J. 2010;24(3):731-9.

\section{Publisher's Note}

Springer Nature remains neutral with regard to jurisdictional claims in published maps and institutional affiliations. 